\title{
TINJAUAN PRAKTIK JUAL BELI TANAMAN TEBU TAKSIRAN DALAM PERSPEKTIF HUKUM ISLAM (Studi Kasus Pada Desa Wonorejo, Singosari, Kabupaten Malang)
}

\author{
Slamet wahyudi'1), Sri Mulyani' ${ }^{2)}$, Lailatul Istiqomah ${ }^{3)}$ \\ Institut Agama Islam Sunan Kalijogo Malang \\ ${ }^{1)}$ Sw080599@gmail.com, ${ }^{2)}$ srimulyani@iaiskjmalang.ac.id, \\ ${ }^{3)}$ lailatulistiqomah@iaiskjmalang.ac.id
}

\begin{abstract}
Abstrak: Penelitian ini bertujuan untuk mengetahui dan menijau tentang praktek jual beli tanaman tebu dalam perspektif hukum ekonomi Islam yang ada di Desa Wonorejo, Kecamatan Singosari, Kabupaten Malang. Penelitian ini merupakan penelitian kualitatif dengan metode yang bersifat deskriptif analisa yaitu suatu penelitian yang bertujuan untuk menggambarkan suatu masalah sedetail mungkin mengenai transaksi jual beli tebu dengan sistem taksir. Sumber data dalam penelitian ini diperoleh melalui observasi, wawancara dan dokumentasi yang dikuatkan dengan studi literatur (kepustakaan), baik berupa buku maupun jurnal ilmiah yang terkait dengan penelitian ini. Hasil dari penelitian ini adalah bahwa praktik akad jual beli taksiran tebu di Desa Wonorejo, Kecamatan Singosari, Kabupaten Malang sudah sesuai dengan rukun dan syarat jual beli, namun pada jual beli taksiran yang dilakukan sebelum tebu dapat dipanen maka termasuk dalam jual beli yang fasid karena mengandung unsur gharar. Sedangkan tata cara dan penentuan besaran harganya sesuai adat yang membolehkan dengan cara taksiran, mereka melakukan kesepatan harga dengan penaksiran yang sesuai dan kesepakatan bersama antara penjual dan pembeli berdasarkan pada standar harga yang berlaku di pasar secara umum.
\end{abstract}

Kata Kunci: Jual Beli Taksiran, Tanaman Tebu, Perspektif Hukum Islam

Abstract: This study aims to identify and review the practice of buying and selling sugar cane in the perspective of Islamic economic law in Wonorejo Village, Singosari District, Malang Regency. This research is a qualitative research with a descriptive analysis method, which is a study that aims to describe a problem in as much detail as possible regarding sugarcane buying and selling transactions with an appraisal system. Sources of data in this study were obtained through observation, interviews and documentation which was corroborated by the study of literature (library), both in the form of books and scientific journals related to this research. The results of this study are that the practice of the sale and purchase agreement of the estimated sugarcane in Wonorejo Village, Singosari District, Malang Regency is in accordance with the pillars and terms of the sale and purchase, but in the sale and purchase of estimates carried out before sugar cane can be harvested it is included in a fasid sale and purchase because it contains gharar element. While the procedure and determination of the price is according to custom which allows by way of estimation, they make a price agreement with an appropriate assessment and mutual agreement between the seller and the buyer based on the standard price prevailing in the market in general.

Keywords: Estimated Sale and Purchase, Sugarcane Plants, Islamic Law Perspective 


\section{PENDAHULUAN}

Sebagai makhluk sosial manusia sudah kodratnya selalu membutuhkan orang lain didalam melaksanakan kegiatan hidupnya sehari-hari untuk memenuhi kebutuhannya. Manusia diciptakan sebagai mahluk yang sempurna dan hidup tak terpisahkan dengan kegiatan muamalah. Muamalah sendiri memiliki arti luas dapat didefinisikan sebagai batasanbatasan atau aturan-aturan (hukum) Allah untuk mengatur insan manusia didalam kaitan yang berhubungan dengan urusan duniawi didalam bersosial. ${ }^{1}$ Seiring dengan perkembangan pada zaman agama Islam merupakan agama yang mengatur tentang seluruh kehidupan yang berhubangan dengan manusia, didalam kegiatan bermuamalah hubungan antar sesama manusia. Seperti didalam pelaksanaan jual beli atau perniagaan. Jual beli merupakan suatu bentuk adanya interaksi antara sesama manusia, sebagai usaha dari manusia tersebut untuk mempertahankan dan memenuhi kebutuhan hidupnya. Jual beli dan perdagangan memiliki permasalahan dan lika-liku yang rumit, jika dilaksanakan tanpa aturan-aturan dan norma yang tepat maka akan menimbulkan bencana, kerugian dan kerusakan dalam masyarakat. ${ }^{2}$

Islam memandang kegiatan jual beli sebagai perbuatan yang mulia sebab dapat dijadikan sebagai salah satu sarana beribadah atau sarana untuk mendekatkan diri pada Allah SWT selama jual beli tersebut tidak bertentangan dengan dasar hukum Islam. Jual beli juga sebagai sarana tolong menolong sesama manusia dalam hal memenuhi kebutuhan hidup. Dari banyaknya sistem jual beli salah satunya adalah jual beli dengan sistem taksiran yang merupakan jual beli sesuatu tanpa ditimbang, ditakar dan tanpa menggunakan ukuran tertentu tetapi menggunakan perhitungan dikira-kira saja. Transaksi tersebut merupakan kegiatan muamalah yang paling banyak ditemukan di masyarakat pedesaan.

Di kalangan para petani transaksi jual beli dengan sistem taksiran sudah biasa terjadi di desa. Dengan demikian transaksi jual beli taksiran tebu dalam penelitian ini adalah pembelian tanaman tebu yang masih diladang dan belum dipanen. Mengingat sistem transaksi ini tidak melalui hitungan dan takaran yang akurat dan juga tidak seperti transaksi secara umum mengharuskan untuk mengetahui hitungan dan takaranya. Di dalam Al-Qur'an Allah

\footnotetext{
${ }^{1}$ Hendi Suhendi, Fiqh Muamalah, (Jakarta: PT. Raja Grafindo Persada, 2007), hlm. 2

2 Hamzah Yakub, Kode Etik Dagang Menurut Islam, (Pola Pembinaan Hidup dalam Berekonomi), (Bandung: Diponegoro 2003), hlm. 13.
} 
SWT memerintahkan agar transaksi jual beli dilaksanakan dengan cara menyempurnakan timbangan dan takaran, sebagaimana Allah telah berfirman dalam surat al-An'am ayat 152 :

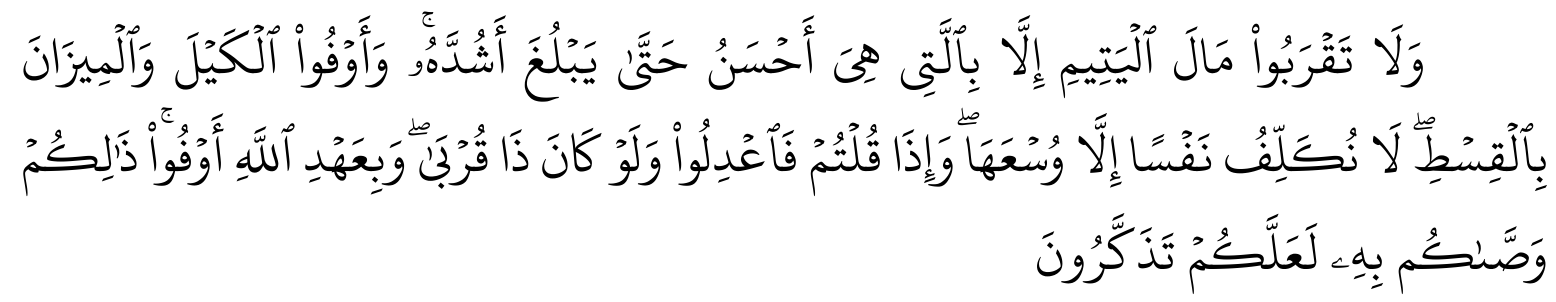

Artinya:

"Dan janganlah kalian dekati harta anak yatim, kecuali dengan cara yang lebih bermanfaat, hingga sampai ia dewasa Dan sempurnakanlah takaran dan timbangan dengan adil. Kami tidak memikulkan beban kepada seseorang, melainkan sekadar ke-sanggupannya Dan apabila kalian berkata, maka hendaklah kalian berlaku adil kendati pun dia adalah kerabat (kalian), dan penuhilah janji Allah. Yang demikian itu diper- intahkan Allah kepada kalian agar kalian ingat". (Q.S Al-An'am: 152)

Transaksi jual beli adalah kegiatan ekonomi yang sudah jauh berkembang sebelum Islam. Islam memperbolehkan Kegiatan jual beli, hal ini dapat diambil dari petunjuk Allah dalam surat an-Nisa': 29 yang artinya :

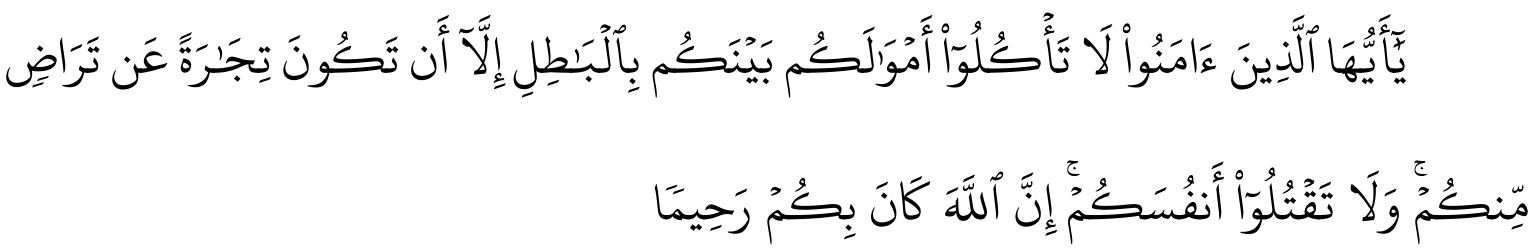

"Hai orang-orang yang beriman, janganlah kamu saling memakan harta sesamamu dengan jalan yang batil, kecuali dengan jalan perniagaan yang Berlaku dengan suka sama-suka di antara kamu". ${ }^{3}$ (Q.S An-Nisa': 29)

Pada ayat diatas sudah dijelaskan bahwa didalam melakukan transaksi jual beli dengan suka sama suka dalam artian bahwa telah terjadi kesepakatan antara pihak penjual dan pembeli dengan tulus dan sama-sama menerima.

Dengan demikian setelah terjadinya akad jual beli menjadikan seseorang memiliki hak dan kewajiban. Diantaranya adalah penjual mempunyai hak untuk memberikan barang dan bagi pembeli memiliki kewajiban untuk membayar sesuai kesepakatan harga.

Dalam hidup bermasyarakat ada banyak transaksi jual beli yang dilaksanakan seperti transaksi jual beli tersebut harus mengandung unsur maslahah antar manusia, dengan begitu jual beli memunculkan sebuah keinginan untuk memperoleh kemudahan dan tanpa

${ }^{3}$ Al qur'an Surat An-Nisa' ayat 29 
mengetahui apakah transaksi perniagaan tersebut sesuai atau bertentangan dengan hukum islam. Masyarakat banyak sekali yang masih melakukan transaksi perniagaan tanpa mengetahui transaksi itu diperbolehkan atau tidak, karena keterbatasan pengetahuan mengenai syarat jual beli yang sesuai hukum Islam.

Dengan demikian terjadinya penaksiran pada transaksi jualbeli tebu menjadi masalah ketika taksiran mengenai hasil dari transaksi jual beli terhadap harga yang telah disepakati dan dibayar, dan ketika sudah tiba waktu panen dan ditimbang ternyata berat tebu lebih banyak sehingga harganya seharusnya menjadi lebih dari harga penjualan, maka si penjual akan merasa dirugikan dan sipembeli akan mendapatkan keuntungan, sebaliknya juga apabila tebu tersebut dipanen ketika ditimbang dan ternyata berat tebu tersebut kurang dari taksiran bobot yang diperkirakan dan harganya menjadi lebih rendah dari harga semula yang disepakati di awal, dan si pembeli akan merasa dirugikan.

Di dalam melaksanakan transaksi jual beli tebu petani menjual tanamannya tersebut saat memasuki masa panen. para petani tebu belum memgetahui secara jelas berat tebu yang masih berupa tanaman yang ada di kebun. Kemudian mengenai harga hal tersebut mengakibatkan salah satu pihak merasa diuntungkan atau dirugikan bagi penjual maupun pembeli.

\section{METODE}

Penelitian ini merupakan penelitian kualitatif dengan pendekatan deskriptif. Data yang digunakan dalam penelitian ini adalah data primer yang diambil melalui observasi, wawancara dan dokumentasi. Untuk menguatkan telaah dan analisis hasil penelitian ini, peneliti menggunakan kajian pustaka berupa buku-buku dan artikel ilmiah yang terkait dengan penelitian ini. Penelitian ini dilakukan di Desa Wonorejo Kecamatan Singosari Kabupaten Malang pada 2 April s/d 10 Juni 2020.

\section{HSIL DAN PEMBAHASAN}

\section{A. Pengertian Jual Beli}

Jual beli adalah kegiatan menukar sebuah barang dengan barang lainnya dengan caracara tertentu. Transaksi Jual beli atau perniagaan secara istilah fiqh disebut al-ba'i secara etimologi berarti menjual atau mengganti. ${ }^{4}$ Menurut Wahbah az-Zuhaily dengan menukar

\footnotetext{
${ }^{4}$ Abdul Rahman Ghazaly, Fiqh Muamalat (Jakarta: Kencana Prenada Media Group, 2010), hal 67.
} 
suatu barang dengan barang lainnya, Kata al-bai'i didalam bahasa Arab terkadang juga digunakan untuk pengertian lawan katanya, yaitu kata as-syira' (beli). Dengan begitu, kata alba'i berarti jual, tetapi kata al ba'i sekaligus juga bisa berarti beli.

Secara terminologi atau istilah jual beli ialah suatu perjanjian untuk tukar menukar barang atau benda memiliki nilai secara sukarela antar kedua pihak penjual dan pembeli, sipembeli menerima barang atau bendanya dan penjualnya juga menerimanya sesuai dengan akad atau perjanjian dan ketentuan yang telah dibenarkan syariat dan disepakati. ${ }^{5}$

Menurut Sayyid Sabiq pengertian jual beli secara terminogi adalah pertukaran harta tertentu dengan harta lain berdasarkan keridhaan antara keduanya atau dengan pengertian lain yaitu memindahkan hak milik dengan hak milik lain berdasarkan persetujuan dan hitungan materi. ${ }^{6}$ Sedangkan jual beli dalam arti terminologi adalah sebagai berikut:

a. Menukar suatu barang dengan barang lainya atau bisa juga barang dengan sejumlah uang untuk melepaskan hak kemilikan dari yang satu kepada yang lainnya atas dasar saling ridho.

b. kepemilikan harta secara tukar-menukar yang sesuai dengan aturan hukum syara'.

c. Saling tukar-menukar benda atau harta, dan saling menerimanya, serta dapat dikelolah (tasharuf) dengan menggunakan ijab dan qobul, dan cara yang sesuai dengan hukum syara'.

d. Saling menukar benda dengan benda lainnya dengan cara yang khusus (dibolehkan).

e. Tukar-menukar benda dengan benda yang lain dengan cara sama-sama merelakan atau memindahkan hak kepemilikan dan ada penggantinya dengan jalan yang diperbolehkan

f. Akad berdasarkan atas dasar penukaran harta benda dengan harta benda lainya, maka jadilah penukaran hak milik secara tetap. ${ }^{7}$

Kalimat jual beli terdiri dari dua kata jual dan beli. Kata jual menunjukan bahwa adanya aktivitas perbuatan menjual, sedangkan beli menunjukkan adanya altivitas membeli. Dengan begitu kalimat jual beli telah menunjukkan adanya dua aktivitas didalam satu peristiwa, dari

\footnotetext{
${ }^{5}$ Hendi Suhendi, Fiqh Muamalah, (Jakarta: Raja Grafindo Persada, 2005), hal 67.

${ }^{6}$ Sayyid Sabiq, Fiqih Sunnah, jilid 4, (Jakarta: Pena Pundi Aksara, 2006), hal121.

7 Syekh Abdurrahmas as-Sa'di, Fiqih Jual Beli: Panduan Praktis Bisnis Syari'ah,(Jakarta: Senayan Publishing, 2008), h. 143.
} 
pihak penjual dan pihak lain yang membeli. Maka didalam hal ini terjadi aktivitas hukum jual beli. 8

Dari beberapa definisi di atas dapat disimpulkan bahwa inti dari jual beli yaitu perjanjian penukaran suatu benda atau barang yang memiliki nilai secara sukarela diantara kedua belah pihak, ada yang menerima benda atau harta dan ada pihak-pihak lain yang menerimanya sesuai dengan akad atau perjanjian dan ketentuan yang telah disepakati dan dibenarkan di dalam syariat .

\section{B. Dalil tentang Jual Beli}

Salah satu bentuk muamalah yang disyariatkan dalam islam adalah aktivitas Jual beli. Oleh karena itu didalam aktivitas jual beli harus berdasarkan kepada ketentuan hukum Islam yang berlaku berdasarkan Al-Qur'an, hadist, ijma' dan qiyas di dalam kaidah fiqh, dan apabila didalam pelaksanaannya sudah mengikuti aturan syariat Islam yang berlaku, maka akan tercipta tujuan dari perniagaan yang diinginkan. Allah telah berfirman didalam Al-Qur'an surat An-Nisa' ayat 29 yang artinya:

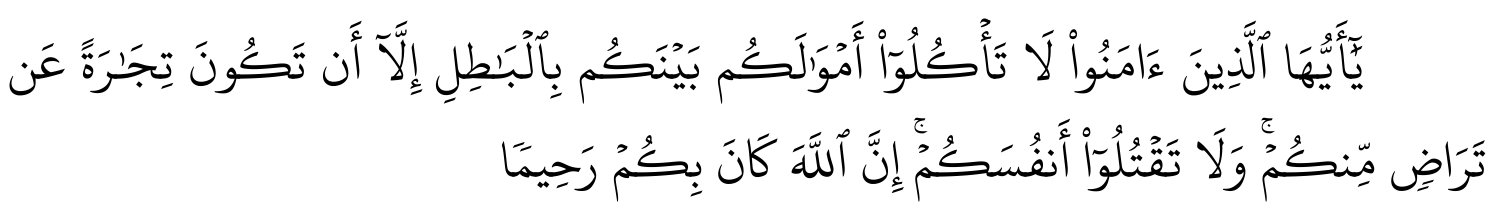

Artinya: "Hai orang-orang yang beriman, janganlah kamu saling memakan harta sesamamu dengan jalan yang batil, kecuali dengan jalan perniagaan yang Berlaku dengan suka sama-suka di antara kamu. dan janganlah kamu membunuh dirimu sesungguhnya Allah adalah Maha Penyayang kepadamu". (Q.S An-Nisa: 29)

Ayat di atas telah menjelaskan kepada kita bahwa larangan memakan harta sesama insan manusia dengan cara yang bathil, juga tentang diperbolehkannya transaksi jual beli dengan cara yang dilakukan atas dasar sukarela antara sesama. Selain melarang memakan harta dengan cara batil, Allah SWT juga melarang memakan harta riba. Sebagaimana firman Allah dalam Al-Qur'an Surat Al-Baqarah ayat 257 yang artinya:

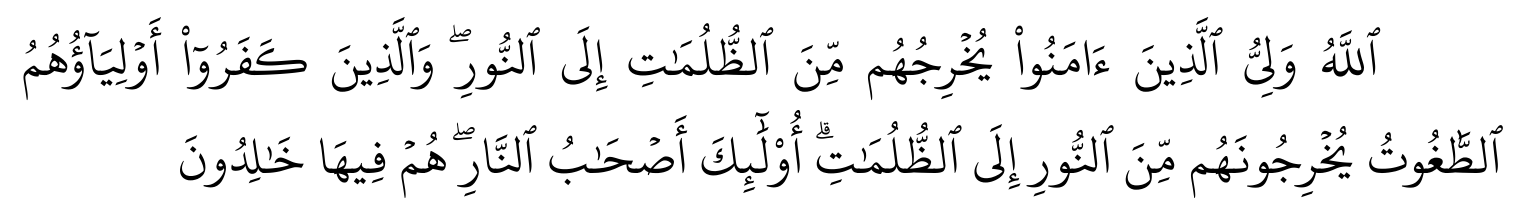

"Orang-orang yang makan (mengambil) riba tidak dapat berdiri melainkan seperti berdirinya orang yang kemasukan syaitan lantaran (tekanan) penyakit gila. Keadaan mereka

\footnotetext{
${ }^{8}$ Suhrawadi. K Lubis, Hukum Ekonomi Islam, (Jakarta: Sinar Grafika, 2000), h. 128.
} 
yang demikian itu, adalah disebabkan mereka berkata (berpendapat), Sesungguhnya jual beli itu sama dengan riba, Padahal Allah telah menghalalkan jual beli dan mengharamkan riba. orang-orang yang telah sampai kepadanya larangan dari Tuhannya, lalu terus berhenti (dari mengambil riba), maka baginya apa yang telah diambilnya dahulu (sebelum datang larangan); dan urusannya (terserah) kepada Allah. orang yang kembali (mengambil riba), Maka orang itu adalah penghuni-penghuni neraka; mereka kekal di dalamnya." (Q.S AlBaqarah ayat 275).

\section{Profil Desa Wonorejo Kecamatan Singosari Kabupaten Malang}

Desa wonorejo terletak di Kecamatan Singosari Kabupaten Malang. Secara topografi Desa Wonorejo termasuk dataran tinggi dengan ketinggian kurang lebih 390 m dari bawah permukaan laut. Desa ini terletak di Kecamatan Singosari paling ujung tenggara sehingga berbatasan langsung dengan Kecamatan Lawang dan Kecamatan Jabung. Desa Wonorejo terdiri dari 3 dusun yaitu Dusun Blandit Barat dengan 3 RW dan 6 RT, Dusun Blandit Timur dengan 2 RW dan 8 RT serta di sebelah utara ada Dusun Banyol yang terdiri dari 2 RW dan 4 RT. Luas daerahya kurang lebih 681.37 Hektar dan memiliki 6.739 jiwa penduduk yang mayoritas pekerjaanya sebagai petani tebu. Didesa Wonorejo memiliki lahan sekitar 290 hektar yang merupakan perkebunan tebu yang sangat potensial, oleh karena itu Sumber Daya Alam (SDA) yang ada pada Desa wonorejo sangat mendukung untuk pengembangan ekonomi maupun sosial budaya. Serta letak desanya yang cukup strategis dan merupakan jalur alternatif kendaraan yang menghubungkan antar desa dan kecamatan yaitu Desa Boro Jabung dan Desa Sidoluhur Kecamatan Lawang. Oleh karena itu keadaan perekonomian pada masyarakat Desa Wonorejo sudah cukup baik serta tingkat kesejahteraan masyarakatnya sudah tergolong sejahtera. Hal ini dapat ditandai dengan banyaknya masyarakat Desa Wonorejo yang menjadi petani dikarenakan mereka mempunyai lahan untuk bercocok tanam sehingga untuk memenuhi kebutuhan sehari-hari mereka bisa memanfaatkan lahan tersebut. Selain itu masyarakat yang memenuhi kebutuhan hidupnya dengan cara bertani juga ada yang berprofesi sebagai PNS, peternak, pedagang dan berbagai profesi lainnya

\section{Praktik Akad dalam Jual Beli Taksiran Tanaman Tebu di Desa Wonorejo Kecamatan Singosari Kabupaten Malang}

Masyarakat Desa Wonorejo merupakan penduduk yang mayoritasnya berprofesi sebagai petani dan peternak. Dapat dilihat dari letak geografisnya yang mendukung karena iklim di Desa Wonorejo sama sebagaimana desa-desa lain di wilayah Kabupaten Malang 
mempunyai musim kemarau dan penghujan. Hal tersebut dapat berpengaruh terhadap pola tanaman yang ditanam di Desa wonorejo Kecamatan Singosari.

Masyarakat Desa Wonorejo biasa melakukan jual beli untuk memenuhi kebutuhan harianya. Di daerah ini sangat cocok untuk digunakan bercocok tanam dikarenakan terdapat sekitar 290 hektar lahan perkebunan yang membuat sebagian besar masyarakatnya menanam tanaman tebu dilahan miliknya. Sehingga tanaman tebu tersebut menjadi objek transaksi jual beli. Tanaman tebu sendiri merupakan tanaman perkebunan yang mempunyai sifat tersendiri, karena dalam batang tebu terdapat zat gula. Tebu juga termasuk kedalam golongan keluarga rumput-rumputan seperti padi, kolonjono, odot, jagung dan lain-lain.

Akad jual beli dipakai petani didalam prakteknya biasanya para petani menawarkan langsung kepada tengkulak (pembeli) atau tengkulak yang datang kerumah si petani untuk membeli tanaman tebu miliknya, kemudian si tengkulak dan petani melihat tebu di kebun secara bersama-sama untuk melihat kondisi tanaman tebunya, dan didalam praktik akadnya biasanya menggunakan akad jual beli dengan sistem taksiran (borongan).

Dari wawancara yang didapat dari seorang petani (penjual) tebu yang bernama Bapak Budiono. Berikut ini kutipan wawancara yang dilakukan peneliti kepada Bapak Budiono selaku petani tebu (penjual):

"Mengapa bapak lebih memilih menjual tebu dengan borongan (taksiran)?". Jawaban Bapak Budinono: "Ya kalau borongan kan lebih gampang mas karena nggak ribet dan praktis, dan juga irit tenaga dan biaya, jadi kita petani ini sudah nggak mikir biaya panen seperti biaya transportasi".

Dari hasil wawancara tersebut dapat kita ketahui bahwa menurut Bapak Budiono selaku penjual tebu menjelaskan bahwa transaksi jual beli tebu dengan cara di taksir menjadi lebih mudah dilakukan. Hal tersebut dikarenakan tidak membutuhkan waktu dan tenaga yang banyak dan tidak mengeluarkkan biaya tambahan untuk menebang tanaman tebu serta menjadi lebih cepat dalam penjualannya. Sebaliknya jika hasil panen tebu dijual dengan cara timbangan maka akan bertambah membengkak pembiayaanya serta memakan banyak waktu dan tenaga dikarenakan harus menebang tebu terlebih dahulu dan juga mempertimbangkan biaya transportasinya,

Dapat kita lihat dari pernyataan tersebut bahwa petani lebih memilih untuk menjual tebunya kepada pembeli (tengkulak) saat masih berada dikebun dengan sistem taksiran. Petani menganggap cara tersebut adalah cara yang mudah dan cepat, serta tidak perlu mengeluarkan biaya tambahan untuk menebang tebu serta tidak memakan banyak waktu 
dan tenaga. Transaksi dengan sistem taksiran menurut para penjual (petani) dirasa lebih mudah serta tidak memakan banyak waktu.

Dan ketika telah usai menaksir tebu maka terjadilah kesepakatan oleh kedua belah pihak untuk melakukan transaksi jual beli hingga terjadilah akad jual beli. Didalam melakukan transaksi perniagaan ini maksud dari akad adalah untuk menunjukkan kerelaan dari kedua belah pihak yang merasa suka sama suka (saling ridho) untuk melakukan kesepakatan dalam transaksi jual beli tebu tersebut.

Ijab qabul yang di gunakan dalam sistem transaksi jual beli tersebut yaitu dengan perkataan atau dengan cara lisan. Misalnya ucapan tengkulak (pembeli) yang dikutip dari hasil wawancara kepada Bapak Tomari sebagai salah satu tengkulak tebu bahwa biasanya dalam transaksi jual beli tengkulang mengatakan:

"Pak tebune kulo tumbase 11 juta nggih". Kemudian penjual (petani) menjawabnya "dereng angsal lekne sakmonten njenengan tambahi". Tengkulak (Pembeli): "ditambahi pinten pak" penjual: "njenengan tambahi 1 juta dados tebune 12 juta, pripun? " pembeli: "Inggih pun kulo tumbase".

Maka disitulah terjadi akad dengan harga tebu yang masih dikebun seharga 12 juta dan terjadi secara sukarela antar kedua belah pihak. Adapun tatacara penyerahan tebu disini berbeda dengan jual beli pada umumnya pada jual beli tebu di Desa wonorejo Kecamatan singosari Kabupaten Malang tidak seperti transaksi yang barangnya langsung diterima langsung oleh pembeli. Dikarenakan didalam transaksi jual beli tebu penyerahannya dari penjual (petani) kepada pembeli (tengkulak) yaitu dengan keadaan tebu yang masih berada di kebun dan belum di tebang dan sudah menjadi tanggung jawab si pembeli.

Misalnya ada kejadian tebu yang mengalami kebakaran maka disitu sudah menjadi tanggung jawab pembeli dikarenakan penjual telah menyerahkan tebunya kepada pembeli, oleh karena itu tebu harus segera ditebang dan dipanen dikarenakan kejadian tersebut bisa saja terjadi dan mengurangi kualitas dan kuantitas tebu itu sendiri.

\section{E. Akad Dalam Jual Beli Taksiran Tanaman Tebu di Desa wonorejo Dalam Perspektif Hukum Islam}

Didalam akad jual beli memiliki syarat dan rukun yang harus dipenuhi, sehingga transaksi jual beli bisa dikatakan sah dalam hukum Islam. Pendapat ulama mengenai rukun jual beli ini memiliki pandangan yang berbeda-beda. Menurut ulama' yang bermazhab Hanafi hanya memiliki satu, ialah ijab dan qobul. Mereka berpendapat bahwa yang menjadi 
rukun didalam transaksi jual beli hanyalah kesukarelaan /keridaan dari kedua belah pihak yang melakukan transaksi jual beli. Sedangkan kerelaan itu sendiri itu datangnya dari hati yang tidak terlihat, untuk itu membutuhkan indikator untuk menujukkan kesukarelaan dari kedua belah pihak yang melakukan akad. Menurut jumhur Ulama berpendapat bahwa rukun jual beli ada empat yaitu:

1. Adanya orang yang melakukan akad

Minimal terdapat 2 orang bisa lebih didalam melaksanakan suatu akad yaitu penjual dan pembeli.

2. Ijab qabul

Ijab qobul adalah pernyataan antar kedua belah pihak yang akan berakad dan kesepakatan diantara penjual dan pembeli untuk melaksanakan akad jual beli. Menurut penganut mazhab Hanafiah ijab qabul adalah "Menetapkan perbuatan yang khusus untuk menunjukkan kesukarelaan, yang timbul dari salah satu pihak yang melakukan akad". Dari definisi itu dapat kita pahami bahwa ijab ialah pernyataan yang disampaikan oleh pihak pertama menunjukkan kerelaan, bisa dinyatakan si penjual, atau si pembeli. Sedangkan arti dari qabul adalah pernyataan yang diungkapkan pihak kedua salah satu pihak didalam melakukan akad. ${ }^{9}$ Adapun yang berhubungan dengan syarat-syarat ijab dan qabul adalah sebagai berikut:

a. kata-kata di dalam ijab qobul harus menunjukkan jual beli yang lazim dan dapat diketahui masyarakat

b. Ijab qabul dilaksanakan didalam suatu majelis. Maksudnya dalam kedua belah pihak yang akan melakukan transaksi jual beli hadir didalam majlis dan ikut membicarakan hal yang sama.

c. Harus ada kesepakatan yang berkenaan dengan barang maupun jenisnya, macam sifatnya, serta harga barang yang akan diperjual belikan, baik kontan atau tidaknya. 10

3. Adanya barang yang dijual untuk diserah terimakan

Adalah objek jual beli dalam bentuk barang yang diperbolehkan dalam hukum Islam ${ }^{11}$

4. Ada nilai tukar pengganti barang

\footnotetext{
${ }_{9}^{9}$ Abdul Azis Dahlan, Ensiklopedi Hukum Islam, Jilid 3, (Jakarta: Ichtiar Baru Van Hoeve, 1996), hal 828

10 Saleh al-Fauzan, Al-Mulakhkhasul Fiqhi, (Jakarta: Gema Insani, 2006), h. 373

11 Syarifuddin, Garis-Garis Besar Fiqh, (Jakarta: Kencana, 2003), h. 218.
} 
Disini sudah disepakati sejumlah yang senilai dengan harga tukar barang yang dijual. Sedangkan syarat itu sendiri adalah suatu perbuatan atau ketentuan-ketentuan yang harus terpenuhi sebelum melaksanakan suatu pekerjaan atau ibadah. Didalam akad jual beli memiliki syarat-syarat yang harus terpenuhi diantaranya adalah sebagai berikut :

1) Syarat bagi para pihak dalam akad jual beli
a. Berakal
b. Orang yang melakukan akad itu, adalah orang yang berbeda. Artinya, seseorang tidak dapat bertindak sebagai pembeli dan penjual dalam waktu yang bersamaan. 12

2) Syarat bagi objek yang akan dijualbelikan
a. Hendaklah benda yang dijualbelikan dapat diketahui secara jelas jenis, kadar dan sifatnya
b. Hendaklah benda yang dijualbelikan dapat diketahui secara jelas jenis, kadar dan sifatnya Suci barangnya
c. Dapat dimanfaatkan
d. Milik orang yang melakukan akad
e. Tidak ada unsur penipuan (gharar)
f. Tidak mengandung kemudharatan (dharar).

3) Syarat terhadap harga sebagai nilai tukar barang

Harga yang diberikan kepada penjual atas barang dengan syarat hendaknya:
a. Sudah diketahui kejelasan jumlahnya.
b. Besaran nominal Uang sebagai nilai tukar dengan barang harus sudah disepakati oleh kedua pihak

\section{PENUTUP}

\section{A. Kesimpulan}

Dari pandangan hukum Islam mengenai hasil penelitian yang dilakukan di Desa Wonorejo Kecamatan Singosari Kabupaten Malang tentang jual beli dengan sistem taksiran tanaman tebu mengenai tata cara akad dan cara penentuan harganya adalah sebagai berikut:

\footnotetext{
12 Abdul Azis Dahlan, Ensiklopedi Hukum Islam, (Jakarta: Pustaka Pelajar, 2011), hal 129.
} 
1. Pada akad transaksi jual beli tebu di Desa Wonorejo Kecamatan Singosari Kabupaten Malang sudah sesuai dengan syarat dan rukun jual beli, sehingga jual beli tersebut dapat dikatakan sah dan dilakukan oleh masyarakat. Sedangkan pada jual beli taksiran tebu dilaksanakan ketika masa panen telah tiba dan tanaman tebunya masih berada dilahan dan belum bisa ditebang, maka jual beli tersebut termasuk jual beli yang fasid (rusak) dan dan tidak bernilai karena didalamnya mengandung unsur gharar.

2. Mengenai tata cara penentuan harganya, mereka melakukanya menggunakan metode penaksiran yang sudah sesuai dengan nilai taksiran dan kesepakatan bersama terkait harganya. Untuk menetapkan harga jual beli dengan metode taksiran tebu sudah sesuai dengan Nabi SAW dan diperbolehkannya didalam Islam. Para pihaknya bebas melakukan transaksi perniagaan dengan cara fair termasuk dengan kebebasan untuk mendapatkan harga serta keuntungan yang ideal untuknya. Harga yang dipakai didalam transaksi jual beli tebu menggunakan harga standar yang berlaku di pasar secara umum. 


\section{DAFTAR PUSTAKA}

Abdurrahman as-Sa'di, Syekh Fiqih Jual Beli: (Panduan Praktis Bisnis Syari'ah),

Jakarta: Senayan Publishing, 2008.

Dahlan, Abdul Azis Ensiklopedi Hukum Islam, Jilid 3, Jakarta: Ichtiar Baru Van Hoeve, 1996

Ghazaly, Abdul Rahman Fiqh Muamalat Jakarta: Kencana Prenada Media Group, 2010.

K Lubis, Suhrawadi. Hukum Ekonomi Islam, Jakarta: Sinar Grafika, 2000.

Sabiq, Sayyid Fiqh Sunnah, Jakarta: Pena Pundi Aksara, 2006.

Saleh al-Fauzan, Al-Mulakhkhasul Fiqhi, Jakarta: Gema Insani, 2006.

Suhendi, Hendi Fiqh Muamalah, Jakarta: PT. Raja Grafindo Persada, 2005.

Syarifuddin, Garis-Garis Besar Fiqh, Jakarta: Kencana, 2003.

Yakub, Hamzah Kode Etik Dagang Menurut Islam, (Pola Pembinaan Hidup dalam Berekonomi), Bandung: Diponegoro 2003 